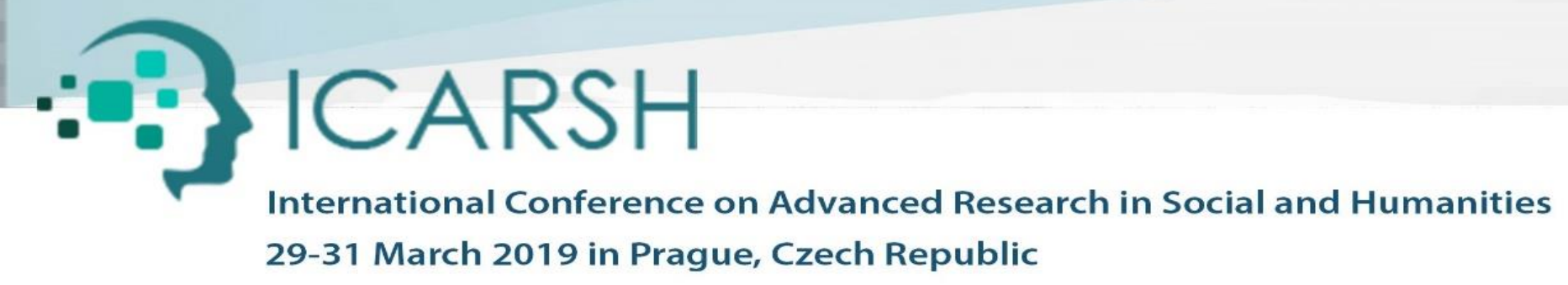

\title{
Concept of the City in Grigol Robakidze's Art
}

\author{
Lili Metreveli \\ Ivane Javakhishvili Tbilisi State University
}

\begin{abstract}
Urban issues turned out to be particularly important to modernist literary discourse and based on its ideological-esthetic principles it created its own original model of the urban paradigm.

It should be noted that fifteen-century age Georgian literature, irrespective of hard social and political challenges, was involved in the processes ongoing in the European literary world for many ages. In 20s of the twentieth century, Georgian modernism shared all conceptual and esthetic innovations of the European modernism, including its interest to the urban problems. Introduction of the spiritual-cultural values and conceptual paradigms of the European modernism in Georgian literary space is associated with the name of Grigol Robakidze. The writer was recognized as the first ideologist of Georgian modernism. In 1930, due to contradiction with the ideological principles of the soviet totalitarian government, Georgian thinker had to leave the country for Berlin, Germany and live there in political emigration.

In his novel "Falestra" dedicated to the European writers, Georgian emigrant writer offers interesting interpretation of the city concept, the central one of the modernist esthetics. The novel describes opposing pair of Berlin and Tbilisi. The author demonstrates the contrasts between these cities, emphasizing geographical, historical, socioeconomic differences: on one hand, Berlin, the center of European urban civilization, desacralized topos and on the other - Tbilisi, center of Caucasus, sacral space. In the novel these two cities create opposing, western and eastern cultural models.

It is notable that in interpreting the phenomenon of the city, the writer's esthetic position has influenced significantly reception of the concept of the city in Georgian modernism thinking space.
\end{abstract}

Keywords: Urban issues city concept modernism 